\title{
A Comparative Study of the Polarographic Behavior of Cobalt(II), Nickel(II), Manganese(II), and Zinc(II) in Azide Solutions
}

\author{
Claudia Giovedi*, and Roberto Tokoro \\ Instituto de Química, Universidade de São Paulo, C.P. 26077, \\ 05599-970 São Paulo - SP, Brazil
}

Received: June 30, 1996; January 9, 1997

\begin{abstract}
O comportamento eletroquímico dos metais cobalto(II), níquel(II), manganês(II) e zinco(II) foi estudado por polarografia em diferentes concentrações do ligante azoteto. As ondas de redução do cobalto(II) e níquel(II) apresentam deslocamento para potenciais mais positivos com o aumento da concentração de azoteto na solução. A antecipação máxima é de $300 \mathrm{mV}$ para o cobalto(II) e de $370 \mathrm{mV}$ para o níquel(II). No caso do zinco(II) registrou-se apenas uma pequena antecipação de $27 \mathrm{mV}$ em baixas concentrações do ligante, ocorrendo em seguida o deslocamento da onda para potenciais mais negativos. $\mathrm{O}$ manganês(II), de comportamento diferente dos demais metais estudados, mostra apenas deslocamento no sentido de aumento da sobretensão.
\end{abstract}

The electrochemical behavior of cobalt(II), nickel(II), manganese(II), and zinc(II) was studied by polarography at several azide concentrations. The reduction waves of cobalt(II) and nickel(II) exhibit a shift of the potential towards more positive values, with the increasing ligand concentration in solution. The maximum anticipation observed is $300 \mathrm{mV}$ for cobalt(II) and $370 \mathrm{mV}$ for nickel(II). In the case of zinc(II), an anticipation of only $27 \mathrm{mV}$ is observed at low ligand concentrations, and for subsequent additions of ligand the reduction wave shifts towards more negative potentials. The behavior of manganese(II) is different, as the reduction wave only shifts towards more negative potentials.

Keywords: azide, catalytic ligand

\section{Introduction}

The pseudohalide ${ }^{1}$ azide, $\mathrm{N}_{3}{ }^{-}$, acts as a bridging ligand in redox reactions in homogeneous media, making the electron transfer easy ${ }^{2}$. In non-homogeneous media, the catalytic effect is also observed due to the adsorption of the ligand on the mercury surface, with the long axis remaining perpendicular to the metal surface ${ }^{3}$. A shift in the reduction wave towards more positive potentials is observed in the presence of the ligand ${ }^{4}$, as compared with the wave of the metal aquo ion. The azide can therefore be classified as a catalytic ligand ${ }^{5}$.

Studies of the electrochemical behavior of some metals in azide media show that the extension of the catalytic action changes from one metal to another ${ }^{6}$. The action of azide as a catalytic ligand depends not only on ligand ad- sorption on the electrode surface, but also on the nature of the metal present.

The results obtained by means of systematic polarographic studies of the electrochemical behavior of some metals belong to the Irving-Williams order ${ }^{7}$ at the presence of azide are shown in this paper.

\section{Experimental}

All reagents were chemically pure or of analytical grade. The azide and perchlorate solutions were standardized by the gravimetric method. The perchlorate solutions of cobalt(II), nickel(II), manganese(II), and zinc(II) were prepared by reacting perchloric acid in excess with the metal carbonate. These solutions were standardized by Atomic Emission Spectroscopy with Inductive Argon Plasma $^{8}$. The free-acid present in the stock solutions was determined by the method of standard addition ${ }^{9}$. The ionic 
strength was maintained constant in $2.0 \mathrm{~mol} / \mathrm{L}$ with the addition of sodium perchlorate.

The normal and differential pulse polarograms were carried out with an EG\&G-PARC 273A potentiostat attached to a Static Mercury Drop Electrode 303A cell stand. The working electrode was a mechanically controlled dropping mercury electrode. The reference electrode was $\mathrm{Ag} / \mathrm{AgCl}$, and the auxiliary electrode was a platinum wire. All solutions were deoxygenated with argon, and the temperature was always $25{ }^{\circ} \mathrm{C}$. The concentrations of cobalt(II), manganese(II), and zinc(II) were $1 \times 10^{-3} \mathrm{~mol} / \mathrm{L}$, and for nickel(II) the concentration was fixed at $0.5 \times 10^{-3}$ $\mathrm{mol} / \mathrm{L}$ to avoid polynuclear complex formation. The azide concentration was varied from 0 to $2.0 \mathrm{~mol} / \mathrm{L}$.

The experiments were carried out with successive additions of a metal solution in $2.0 \mathrm{~mol} / \mathrm{L} \mathrm{NaN}_{3}$ to a solution in $2.0 \mathrm{~mol} / \mathrm{L} \mathrm{NaClO}_{4}$ of the same metal. Since the metal concentration in both solutions was the same, its concentration and the ionic strength remained constant, changing only the azide concentration.

Perchloric acid was added to solutions in the experiments with cobalt(II) and zinc(II) in order to prevent the hydrolysis of the metal. The addition of strong acid to the system results in a buffer solution formed by the weak acid, $\mathrm{HN}_{3}$, and its salt $\mathrm{NaN}_{3}$. The correct acid concentration was determined using the Henderson-Hasselbach equation ${ }^{10}$. The addition of perchloric acid was avoided as possible due to the great oxidant power of the $\mathrm{HN}_{3}$ formed, which can cause catalytic waves, as observed in the cobalt(II)/azide system $^{11}$.

\section{Results and Discussion}

The normal pulse reduction wave of cobalt(II) in azide media shows a progressive anticipation, with a split into two waves with $\mathrm{E}_{1 / 2}$ equal to -1.070 and $-1.370 \mathrm{~V} v s$. $\mathrm{Ag} / \mathrm{AgCl}$, respectively (Fig. 1). The current associated with the first wave $\left(\mathrm{E}_{1 / 2}=-1.070 \mathrm{~V}\right)$ increases with the gradual

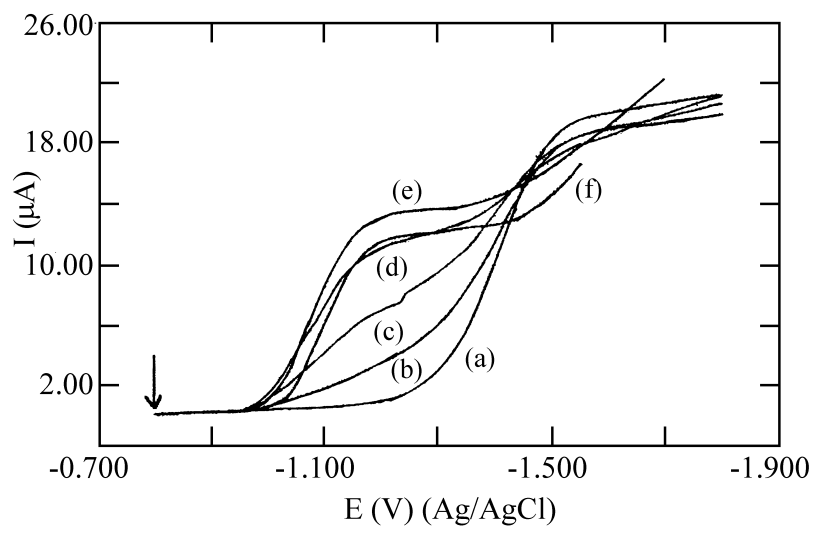

Figure 1. Normal pulse polarograms for $1 \times 10^{-3} \mathrm{~mol} / \mathrm{L}$ cobalt(II) solution at ionic strength $2.0 \mathrm{~mol} / \mathrm{L}$ with azide concentrations: (a) 0 , (b) 0.05 , (c) 0.10 , (d) 0.20 , (e) 1.0, and (f) 2.0. Initial potential: $-0.8 \mathrm{~V}$; scan rate: $10 \mathrm{mV} \mathrm{s}^{-1}$; scan increment: $2 \mathrm{mV}$; pulse width: $50 \mathrm{~ms}$. addition of azide. With the second wave $\left(\mathrm{E}_{1 / 2}=-1.370 \mathrm{~V}\right)$ the opposite occurs: the current decreases until it disappears for an azide concentration equal to $0.70 \mathrm{~mol} / \mathrm{L}$. In previous research it was shown that the first wave corresponds to the reduction of the metal complex species, and the second, to the free uncomplexed metal ${ }^{12}$. The split of the waves originates in the fact that the polarographic experiments involve time intervals too short to permit the transformation of the metal aquo ion into the complexed species after the later are reduced on the mercury surface. At high azide concentrations, there is almost no metal aquo ion in solution, and the reduction wave of this species disappears.

The normal pulse polarograms recorded for cobalt(II) show a signficant decrease in the value of the limiting current at high azide concentrations, probably due to the kinetic problems associated with the electrode process under these conditions.

The maximum anticipation of the total reduction wave in azide media as compared with the metal reduction wave in perchorate media is obtained for the addition of $0.70 \mathrm{~mol} / \mathrm{L}$ azide. This anticipation is equal to $300 \mathrm{mV}$.

In the interval of azide concentration from 0.7 to $1.0 \mathrm{~mol} / \mathrm{L}$, the $\mathrm{E}_{1 / 2}$ of the reduction wave remains practically constant, and at concentrations higher than $1.0 \mathrm{~mol} / \mathrm{L}$ a shift in the reduction wave occurs towards more negative potentials. The maximum value, $30 \mathrm{mV}$, is obtained for $2.0 \mathrm{~mol} / \mathrm{L}$ azide.

The polarographic reduction wave of nickel(II) in perchlorate media shows $\mathrm{E}_{1 / 2}$ equal to $-1.020 \mathrm{~V} v s$. $\mathrm{Ag} / \mathrm{AgCl}$. With the addition of azide, a splitting into two waves occurs with $\mathrm{E}_{1 / 2}$ equal to -0.650 and $-1.020 \mathrm{~V} v s$. $\mathrm{Ag} / \mathrm{AgCl}$, respectively (Fig. 3). This splitting is observed for ligand concentrations from 0.05 to $0.10 \mathrm{~mol} / \mathrm{L}$, and the first wave $\left(E_{1 / 2}=-0.650 \mathrm{~V}\right)$ increases, while the second decreases with the progressive addition of azide. For ligand concen-

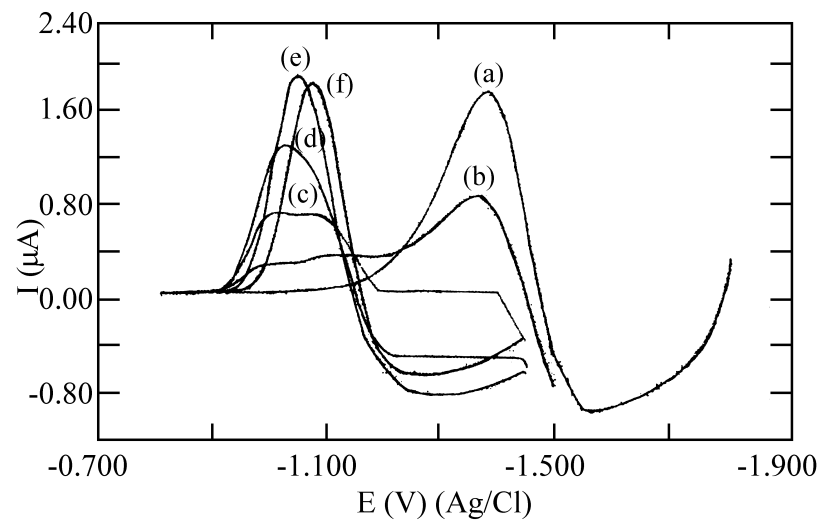

Figure 2. Differential pulse polarograms for $1 \times 10^{-3} \mathrm{~mol} / \mathrm{L}$ cobalt(II) solution at ionic strength $2.0 \mathrm{~mol} / \mathrm{L}$ with azide concentrations: (a) 0 , (b) 0.05 , (c) 0.10 , (d) 0.20 , (e) 1.0 , and (f) 2.0 . Scan rate: $10 \mathrm{mV} \mathrm{s}^{-1}$; scan increment: $2 \mathrm{mV}$; pulse width: $50 \mathrm{~ms}$; pulse height: $25 \mathrm{mV}$. 


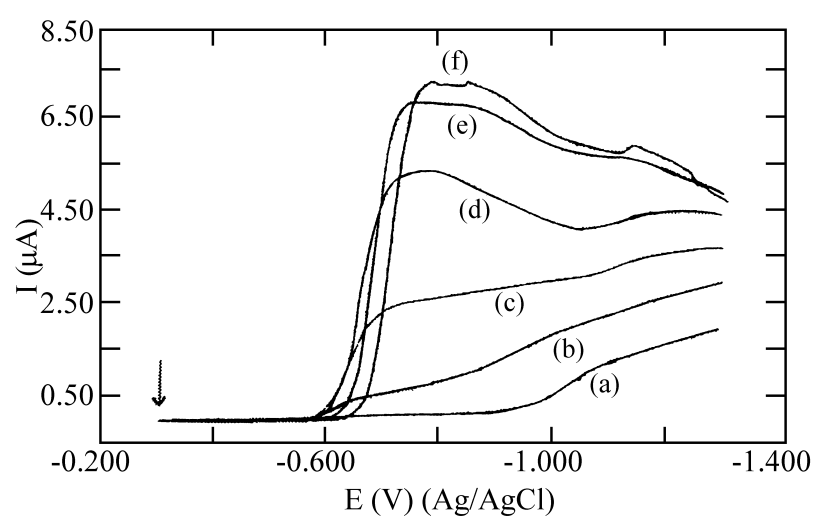

Figure 3. Normal pulse polarograms for $0.5 \times 10^{-3} \mathrm{~mol} / \mathrm{L}$ nickel(II) solution at ionic strength $2.0 \mathrm{~mol} / \mathrm{L}$ with azide concentrations: (a) 0 , (b) 0.05 , (c) 0.10 , (d) 0.20 , (e) 1.0, and (f) 2.0. Initial potential: $-0.3 \mathrm{~V}$, scan rate: $10 \mathrm{mVs}^{-1}$; scan increment: $2 \mathrm{mV}$; pulse width: $20 \mathrm{~ms}$.

trations equal to $0.15 \mathrm{~mol} / \mathrm{L}$ or higher, the curves show only one wave with $\mathrm{E}_{1 / 2}$ equal to $-0.650 \mathrm{~V}$.

The variation of the reduction wave height of nickel(II) with the addition of azide is not linear with azide concentration. A current limit is reached with the addition of 0.50 $\mathrm{mol} / \mathrm{L}$ azide. For the aquo ion reduction wave, the current decreases rapidly, and it becomes zero near $0.20 \mathrm{~mol} / \mathrm{L}$ azide.

When the azide concentration is higher than $1.0 \mathrm{~mol} / \mathrm{L}$, the reduction wave shifts towards more negative potentials, and the most negative value of $E_{1 / 2}$ (corresponding to a shift of $50 \mathrm{mV}$ ) was obtained for an azide concentration of $2.0 \mathrm{~mol} / \mathrm{L}$.

The current maximum recorded for the reduction wave of nickel(II) was reported in previous papers for the ligands thiosulfate ${ }^{13}$ and thiocyanate ${ }^{14}$, however the explanation of the presence of this maximum is not given. Previous papers on maxima in pulse polarography reported that the increase in the pulse width can eliminate the problem ${ }^{15,16}$. This artifice was used in the experiments with nickel(II), and the results obtained with pulse widths longer than $50 \mathrm{~ms}$ showed that the current maxima decrease, but are not completely eliminated. This indicates that in the nickel(II)/ azide system there are other problems in the electrode process, resulting in the maxima and the increase in the limiting current observed in both techniques used.

The currents recorded by means of both of the techniques used (Figs. 3 and 4) show a significant increase with increasing azide concentration. This fact can be explained for experiments with differential pulse polarography, assuming that this technique is sensitive to the kinetic effects of the electrode process ${ }^{17}$. Thus, the increase in the current denotes a minor irreversibility of the electrode process.

The effect of azide on the reduction wave from manganese(II) differs completely of the results obtained for cobalt(II) and nickel(II). The addition of azide to a solution of

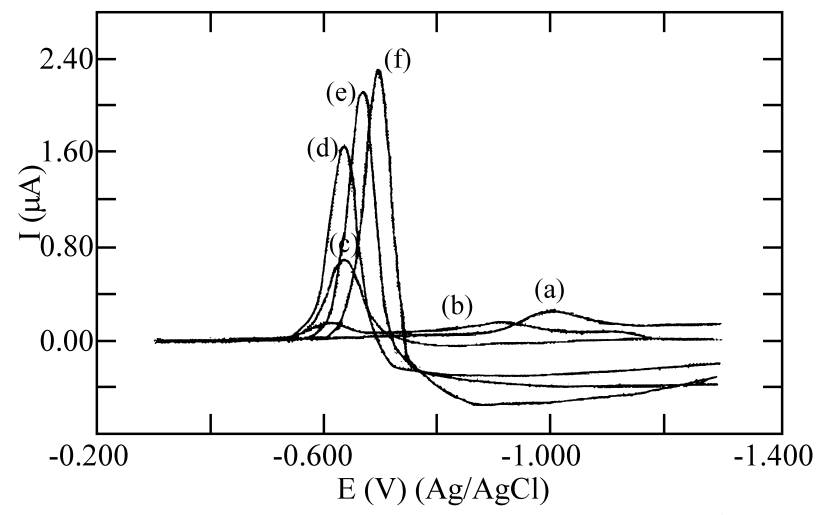

Figure 4. Differential pulse polarograms for $0.5 \times 10^{-3} \mathrm{~mol} / \mathrm{L}$ nickel(II) solution at ionic strength $2.0 \mathrm{~mol} / \mathrm{L}$ with azide concentrations: (a) 0, (b) 0.05, (c) 0.10, (d) 0.20, (e) 1.0, and (f) 2.0. Scan rate: $10 \mathrm{mV} \mathrm{s}^{-1}$; scan increment: $2 \mathrm{mV}$; pulse width: $20 \mathrm{~ms}$; pulse height: $25 \mathrm{mV}$.

manganese(II), at an ionic strength of $2.0 \mathrm{~mol} / \mathrm{L}$ perchlorate, causes a gradual shift in the reduction wave towards more negative potentials (Fig. 5). The maximum shift, 140 $\mathrm{mV}$, was recorded for the addition of $2.0 \mathrm{~mol} / \mathrm{L}$ azide.

The differential pulse polarograms for manganese(II) show a significant decrease in current for azide concentrations higher than $0.50 \mathrm{~mol} / \mathrm{L}$ (Fig. 6), indicating a decrease in the reversibility of the electrode process.

For zinc(II), the addition of azide at concentrations lower than $0.030 \mathrm{~mol} / \mathrm{L}$ causes a shift in the reduction wave towards more positive potentials in comparison with the wave of the metal aquo ion (Fig. 7). The maximum anticipation observed was $27 \mathrm{mV}$.

For azide concentrations higher than $0.030 \mathrm{~mol} / \mathrm{L}$, the reduction wave starts to shift towards more negative potentials. The maximum shift to the negative potential, $96 \mathrm{mV}$, was obtained with the addition of $2.0 \mathrm{~mol} / \mathrm{L}$ azide.

An important fact observed for zinc(II) in the polarograms obtained in both techniques (Figs. 7 and 8) is the clear modification of the reversibility in the presence of

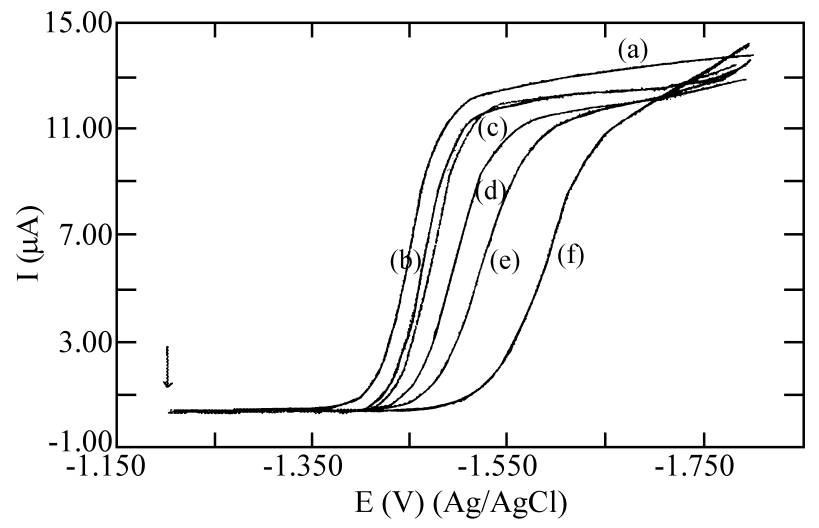

Figure 5. Normal pulse polarograms for $1 \times 10^{-3} \mathrm{~mol} / \mathrm{L}$ manganese(II) solution at ionic strength $2.0 \mathrm{~mol} / \mathrm{L}$ with azide concentrations: (a) 0 , (b) 0.10 , (c) 0.20 , (d) 0.50 , (e) 1.0, and (f) 2.0. Initial potential: $-1.2 \mathrm{~V}$; scan rate: $10 \mathrm{mV} \mathrm{s}^{-1}$; scan increment: $2 \mathrm{mV}$; pulse width: $50 \mathrm{~ms}$. 


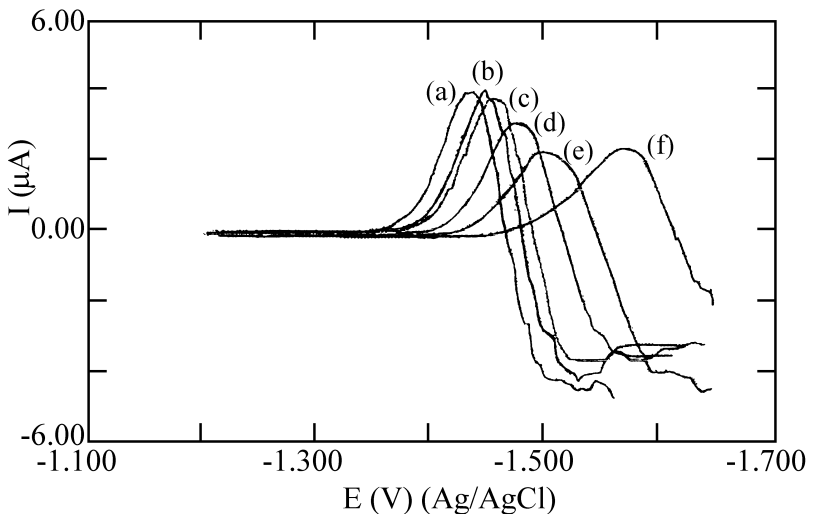

Figure 6. Differential pulse polarograms for $1 \times 10^{-3} \mathrm{~mol} / \mathrm{L}$ manganese(II) solution at ionic strength $2.0 \mathrm{~mol} / \mathrm{L}$ with azide concentrations: (a) 0, (b) 0.10 , (c) 0.20, (d) 0.50, (e) 1.0, and (f) 2.0. Scan rate: $10 \mathrm{mV} \mathrm{s}^{-1}$; scan increment: $2 \mathrm{mV}$; pulse width: $50 \mathrm{~ms}$; pulse height: $25 \mathrm{mV}$.

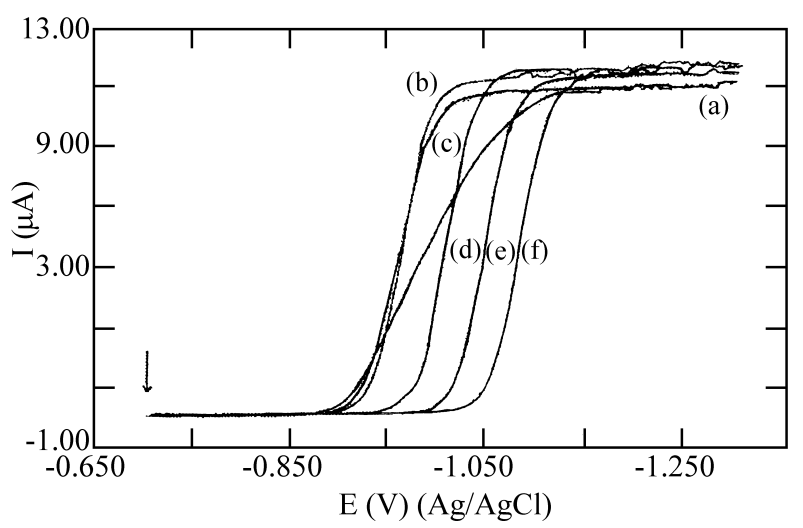

Figure 7. Normal pulse polarograms for $1 \times 10^{-3} \mathrm{~mol} / \mathrm{L}$ zinc(II) solution at ionic strength $2.0 \mathrm{~mol} / \mathrm{L}$ with azide concentrations: (a) 0 , (b) 0.03 , (c) 0.10 , (d) 0.50 , (e) 1.0, and (f) 2.0. Initial potential: $-0.7 \mathrm{~V}$; scan rate: $10 \mathrm{mV} \mathrm{s}^{-1}$; scan increment: $2 \mathrm{mV}$; pulse width: $50 \mathrm{~ms}$.

azide. Small concentrations of azide are sufficient to cause a great change in the reversibility of the electrode process, as observed in the normal pulse polarograms - the curves in the presence of azide are more vertical than the curve obtained in $2.0 \mathrm{~mol} / \mathrm{L}$ perchlorate - and the differential pulse polarograms are more pointed in azide media.

\section{Conclusions}

The results obtained for cobalt(II), nickel(II), manganese(II), and zinc(II) in azide medium confirmed the catalytic action of the ligand on the reduction process, and the fact that this action is dependent on the metal present.

The catalytic effect was higher for nickel(II), followed by cobalt(II) and zinc(II). For manganese(II) this effect was not observed.

The results obtained show that the overall action of the azide on the metal reduction process is a result of two factors: 1) the adsorption of the ligand on the mercury surface, forming a bridge that makes the electron transfer easier (ki-

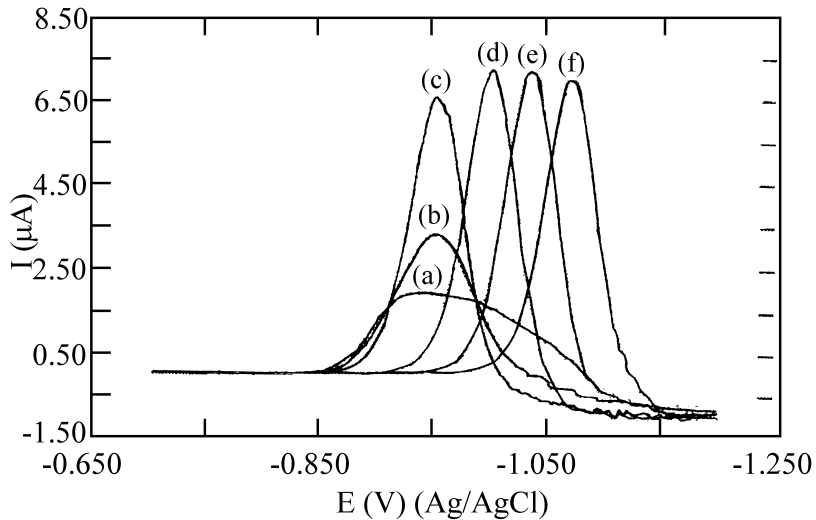

Figure 8. Differential pulse polarograms for $1 \times 10^{-3} \mathrm{~mol} / \mathrm{L}$ zinc(II) solution at ionic strength $2.0 \mathrm{~mol} / \mathrm{L}$ with azide concentrations: (a) 0 , (b) 0.03 , (c) 0.10 , (d) 0.50 , (e) 1.0, and (f) 2.0 . Scan rate: $10 \mathrm{mV} \mathrm{s}^{-1}$; scan increment: $2 \mathrm{mV}$; pulse width: $50 \mathrm{~ms}$; pulse height: $25 \mathrm{mV}$.

netic factor), consequently shifting the wave towards more positive potentials, and 2) the formation of more stable complexed species with a higher number of more stable coordinated ligands which need a higher overpotential to be reduced (thermodynamic factor), and therefore shifting the wave towards more negative potentials. Another possible important factor in the overall results obtained is the chemical kinetics of substitution of the water molecules by azide, which may be an explanation for the decrease in the limiting current (at high azide concentrations) observed for cobalt(II).

For cobalt(II) and nickel(II), the electrochemical kinetic factor is preponderant up to azide concentrations of 0.70 and $0.50 \mathrm{~mol} / \mathrm{L}$, respectively, and then the reduction waves shift towards more positive potentials. After an azide concentration of $1.0 \mathrm{~mol} / \mathrm{L}$ for both metals, the thermodynamic factor becomes responsible for the shift of the reduction waves towards more negative potentials, due to the formation of more stable complexes.

For zinc(II), low azide concentrations (lower than $0.030 \mathrm{~mol} / \mathrm{L}$ ) are sufficient to make the electron transfer easier, and makes the electrode process more reversible. For higher azide concentrations, however, a shift towards more negative potentials is observed, indicating the preponderance of the thermodynamic factor.

The values of the thermodynamic formation constants $\left(\beta_{1}\right)$ for species with one coordinated azide molecule $\left(\mathrm{M}\left(\mathrm{N}_{3}\right)^{+}\right)$for the studied metals, at an ionic strength of $2.0 \mathrm{~mol} / \mathrm{L}$ sodium perchlorate are $4.2^{18}, 5.7^{19}, 5.8^{20}$, and $6.0^{21}(\mathrm{~mol} / \mathrm{L})^{-1}$, for $\mathrm{Mn}(\mathrm{II}), \mathrm{Co}(\mathrm{II}), \mathrm{Ni}(\mathrm{II})$, and $\mathrm{Zn}(\mathrm{II})$, respectively.

The low value observed for manganese(II) explains the electrochemical behavior of this metal in azide media. The interaction between the metal and the ligand adsorbed on the mercury surface being weak, the effect of the ligand as a bridge is not verified. The presence of the adsorbed ligand 
makes the electron transfer from the electrode to the metal aquo ion present in solution more difficult, shifting the reduction wave towards more negative potentials.

\section{Acknowledgments}

The authors thank FAPESP (Fundação de Amparo à Pesquisa do Estado de São Paulo) for financial support.

\section{References}

1. Golub, A.M.; Kolher, H.; Skopenko, V.V. Chemistry of Pseudohalides; Elsevier; New York ,1986, p 28.

2. Beck, W.; Fehlammer, W.P. In Main Group Elements: Groups V and VI; Butterworths; London, 1972, p 286.
3. Moteo, A.J.; Gonzales, E.R.; Avaca, L.A. Can. J. Chem. 1986, 64, 413.

4. Anson, F.C. Acc. Chem. Res. 1975, 8, 400.

5. Ruvinskii, O.E.; Tur'yan, Ya.I. J. Anal. Chem. USSR 1976, 3, 460.

6. Senise, P.; Neves, E.A. An. Acad. Brasil. Ciênc. 1969, $41,333$.

7. Irving, H.; Williams, R.J.P. Analyst 1952, 77, 813.

8. Mermet, J.M. Spectroscopic Diagnostics: Basic Concepts in Inductively Coupled Plasma Atomic Emission Spectroscopy; Wiley Interscience; New York, 1987.

9. Neves, E.A.; Silva, T.V. In Anais do $4^{\circ}$ Simpósio Brasileiro de Eletroquímica e Eletroanalítica 1984, São Carlos - SP, Brazil, p 63.

FAPESP helped in meeting the publication costs of this article 
10. Russel, J.B. In Química Geral; McGraw-Hill; São Paulo, 1982, p 522.

11. Tokoro, R.; Neves, E.A. J. Electroanal. Chem. 1981, $125,115$.

12. Giovedi, C. In Estudo da Redução do Cobalto(II) em Meio Aquoso de Azoteto de Sódio por Polarografia de Pulso; Master's Thesis, Instituto de Química da Universidade de São Paulo, São Paulo, 1994.

13. Davis, A. Anal. Chem. 1958, 30, 1729.

14. Tanaka, N. Bull. Chem. Soc. Japan 1950, 23, 253.

15. Bolzan, J.A. Coll. Czech. Chem. Commun. 1987, 52, 587.

16.
Bolzan, J.A. Coll. Czech. Chem. Commun. 1988, 53, 721.

17. Osteryoung, J.; Hasebe, K. Rev. of Polarogr. (Kyoto) 1976, 22,1.

18. Moya, H.D. In Estudo Potenciométrico dos Equilíbrios no Sistema Manganês(II)/Azoteto;Master's Thesis, Instituto de Química da Universidade de São Paulo, São Paulo, 1992 .

19. Neves, E.A.; Tokoro, R.; Suárez, M.E.V. J. Chem. Res. (M) 1979, 4401.

20. Suárez, M.E.V.; Neves, E.A. Polyhedron 1992, 11, 759.

21. Neves, E.A.; Sant'Agostino, L. Anal. Chim. Acta 1970, 49, 597. 